\title{
РЕГУЛЯТОРИ ПРОГРАМОВАНОЇ КЛІТИННОЇ СМЕРТІ ІЗОЛЬОВАНИХ МОДЕЛЬНИХ СИСТЕМ
}

\author{
Д. В. Ватліцов \\ Національна медична академія післядипломної освіти імені П. Л. Шупика
}

\begin{abstract}
Розвиток технологій створює передумови виникнення нових підходів розуміння інсормації та формування принципово нових засад розуміння біологічних об'єктів. Метою роботи було дослідження регуляторів активації програмованої клітинної загибелі в ізольованій модельній системі. Проводили дослідження параметрів старіючої культури клітин за допомогою проточної цитометрії. Було сформовано уявлення про те, що регуляція клітинної загибелі відбувається за рахунок змін концентрацій іонів металів, а зростання їх зовнішньоклітинної концентрації є передумовою створення негативного вектора градіента надходження в клітини. Показано, що регуляторами процесів програмованої клітинної смерті можуть виступати іони.
\end{abstract}

\section{THE PROGRAMED CELL DEATH REGULATORS OF ISOLATED MODEL SYSTEMS}

\author{
Shupyk National Medical Academy of Postgraduate Education
}

\begin{abstract}
The technology evolution creates the prerequisites for the emergence of new informational concept and approaches to the formation of a fundamentally new principles of biological objects understanding. The aim was to study the activators of the programmed cell death in an isolated system model. Cell culture aging parameters were performed on flow cytometer. It had formed the theory that the changes in the concentrations of metal ions and increase their extracellular concentration had formed a negative gradient into the cells.regulation of cell death. It was shown that the metals ions concentrations controls programmed cell death.
\end{abstract}

Вступ. Холістичний підхід до вивчення біологічних об'єктів дає можливість оперувати критеріями процесів цілісної системи, а не виокремлених із загального комплексу подій, що відбуваються в клітині незалежно від часу як параметра події. Слід зазначити, що в цьому випадку під поняттям «подія» мається на увазі будь-яке явище, що призводить до змін у системі.

Сучасний розвиток технологій дає можливість вивчати надзвичайну кількість параметрів одночасно, проте обробляти таку кількість даних наразі немає можливості. Однією з причин цього явища $\epsilon$ відсутність уніфікованої класифікації процесів та подій. Раніше нами було запропоновано формалізовану класифікаційну модель подій, що є факторами змін балансу процесів клітин; також було сформульовано теорію тригер-залежних процесів у клітинах. Це дало можливість виокремити рівні організації подій, які можуть активувати ланцюги перетворень, що призводять до програмованої клітинної смерті.

Мета роботи: дослідити регулятори активації шляхів настання програмованої клітинної заги- белі структурних одиниць ізольованої модельної системи (культури клітин).

Матеріал та методи. Дослідження проводились на зразках перещеплюваної суспензіонної культури клітин Namalwa (лімфома Беркіта). Клітини поміщали в культуральне поживне середовище без відновлення поживних речовин із метою моделювання процесів природного старіння. Щогодини відбирали зразок та проводили дослідження клітин з ознаками клітинної загибелі. Проводили диференціювання клітин за типом загибелі та стадією апоптозу з використанням реагентів AnnexinV apoptosis detection kit I (BD Bioscience) та Rhodamine123 (Sigma Aldrich) на проточному цитометрі PAS (Німеччина).

Результати й обговорення. 3 використанням бази взаємодій відомих та передбачуваних біомолекул STRING та Panther було досліджено та оцінено відомі ланцюги розвитку клітинної загибелі. Результатом дослідження стало формування уявлення про те, що регуляція клітинної загибелі відбувається за рахунок змін концентрацій іонів металів та зростання їх зовнішньоклітинної кон-

(С. Д. Ватліцов 
центрації, що є передумовою створення негативного вектору градієнта надходження в клітини, що підтверджується даними щодо інтактності цитоплазматичної мембрани (рис.1).

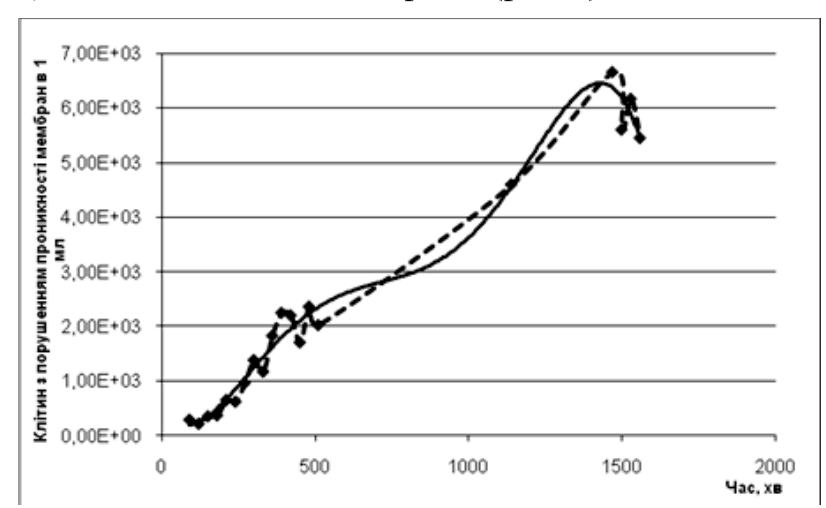

Puc. 1. Зміна концентрації клітин із порушенням проникності цитоплазматичної мембрани в динаміці

Виходячи $з$ результатів роботи з базою даних, було розроблено схеми експериментального дослідження, метою якого було визначення механізмів розвитку програмованої клітинної загибелі. Динаміка змін кількості клітин із ознаками апоптозу старіючої культури мала S-подібний характер. Проте дослідження виявило 2-годинну періодичність наростання/зменшення кількості клітин із зазначеними ознаками ранньої стадії апоптозу.

Висновки. Наразі застосування холістичного підходу до досліджень біологічних об’єктів $\epsilon$ переважним. Такий підхід поєднує проведення модельних досліджень із використанням баз даних для визначення параметрів, які слід дослідити, отримання експериментальних даних та створення цілістної картини процесу, що досліджується, з урахуванням усіх відомих та можливих варіантів проходження цього процесу як компонента цілісної системи.

Показано, що регуляторами процесів програмованої клітинної смерті можуть виступати речовини, що відносяться до рівня взаємодії іонів, оскільки порушується внутрішньоклітинна концентрація регуляторів активації тригерів загибелі. 